\title{
Analisis Materi Ajar Konsep Laju Reaksi Pada Buku Teks Kimia SMA/MA
}

\author{
Sakti*, Abdul Hadjranul Fatah, Maya Erliza Anggraeni \\ Program Studi Pendidikan Kimia, Jurusan Pendidikan MIPA, FKIP, Universitas \\ Palangka Raya, Indonesia \\ Email: sakti115026@gmail.com
}

Diterima: 05 Maret 2020; Disetujui: 20 Maret 2020; Diterbitkan: 25 Maret 2020

\begin{abstract}
ABSTRAK
Penelitian ini bertujuan untuk: (1) mendeskripsikan kesesuaian konsep laju reaksi pada materi ajar kimia SMA/MA kelas XI terhadap kurikulum 2013, (2) mendeskripsikan struktur makro dalam materi ajar kimia SMA/MA kelas XI pada konsep laju reaksi, dan (3) mendeskripsikan proposisi apa saja yang berpotensi kesalahan konsep yang terdapat dalam materi ajar kimia SMA/MA kelas XI pada konsep laju reaksi. Penelitian ini merupakan jenis penelitian deskriptif. Objek penelitian ini yaitu: (1) Buku teks kimia SMA/MA kelas XI. Data yang diperoleh dianalisis secara deskriptif. Susunan makro wacana laju reaksi pada buku teks A pembahasan konsep dimensi elaborasi mencapai level 4 dan dimensi progresi terdapat 4 konsep pada level 2. Susunan makro wacana laju reaksi pada buku teks B pembahasan konsep dimensi elaborasi mencapai level 4 dan dimensi progresi terdapat 5 konsep pada level 2. Proposisi yang berpotensi kesalahan konsep pada buku teks A yaitu penjelasan katalis dan tetapan laju reaksi. Proposisi yang berpotensi kesalahan konsep pada buku teks B yaitu pada rumus molaritas, penulisan koefisien reaksi, penjelasan pengaruh luas permukaan, penjelasan grafik orde reaksi 0 , orde reaksi 1 , orde reaksi 2 , orde reaksi -2 , dan orde reaksi 1/2.
\end{abstract}

Kata Kunci: analisis, konsep, laju reaksi, materi ajar

\section{PENDAHULUAN}

Kimia merupakan salah satu ilmu sains yang sangat erat kaitannya dengan kegidupan sehari-hari. Menurut Chang (2003) ilmu kimia jauh lebih luas dari pada sekedar angka-angka, rumus, dan teori yang abstrak. Kimia adalah ilmu logis yang dipenuhi dengan gagasan dan berbagai aplikasi yang menarik. Ilmu kimia mengkaji konsep-konsep yang sederhana, namun ada beberapa konsep yang tergolong rumit sehingga membutuhkan perhatian yang lebih besar untuk dapat menguasainya. Tidak hanya konsep, ilmu kimia juga berisi hitungan matematika seperti logaritma, integral, maupun diferensial.

Salah satu materi kimia yang dianggap sulit oleh siswa yaitu laju reaksi yang merupakan cabang kimia dari kinetika kimia (Kirik \& Boz, 2012). Berdasarkan penelitian Justi (2002) menyatakan bahwa laju reaksi merupakan salah satu materi kimia yang paling sulit untuk dipahami dan banyak siswa yang mengalami miskonsepsi alasannya memuat perhitungan matematis dan banyak faktor yang menyebabkan kenaikan laju reaksi. Padahal materi laju reaksi merupakan bagian dari kajian kimia yang bersifat fundamental dan menjelaskan banyak konsep kimia yang penting (Kolomuc \& Tekin, 2011). 
Kesulitan siswa dalam memahami suatu konsep akan menghambat siswa dalam memahami konsep berikutya. Kesulitan tersebut disebabkan oleh karakterisitik kimia yang mempunyai konsep yang saling berkaitan antara satu sama lainya. Misalnya materi laju reaksi yang menjadi konsep pra syarat untuk memahami materi kesetimbangan kimia (Kaya \& Geban, 2012). Hal ini berarti ketidakmampuan siswa dalam memahami suatu konsep akan berakibat pada ketidak pahaman terhadap konsep berikutnya (Darmana, dkk 2013). Selain itu, materi laju reaksi penting dipelajari sebagai dasar bagi ilmu terapan di bidang industri, kedokteran dan lingkungan. Contohnya suatu katalis berperan meningkatkan laju reaksi antara obat tertentu dengan zat yang terdapat dalam tubuh yang digunakan sebagai dasar pengembangan suatu pengobatan medis baru (Justi, 2002). Sehingga, materi laju reaksi, penting untuk dipelajari oleh siswa.

Fenomena yang ditemukan di lapangan, buku teks pelajaran yang beredar dan digunakan oleh siswa menurut Anwar (2014) buku-buku teks pelajaran tersebut banyak menuai kritik terutama dalam hal kebenaran konsep. Menurut penelitian yang dilakukan oleh Kaya dan Geban (2012) menemukan dari 25 butir soal dikembangkan, terdapat 20 buah miskonsepsi yang dialami siswa pada materi laju reaksi. Penelitian serupa juga menemukan bahwa terdapat 49 buah miskonsepsi siswa yang dideteksi melalui tes diagnotik Two-Tier (Sari, 2013). Berdasarkan penelitian tersebut kebenaran konsep menjadi kriteria penting yang harus diperhatikan oleh penulis buku teks pelajaran kimia.

Konsep yang benar menjadi landasan dalam pembentukan pemahaman yang benar dan utuh. Pemahaman yang tidak utuh mengakibatkan siswa sulit untuk memahami materi tersebut. Akibatnya juga berdampak terhadap materi yang dipelajari oleh siswa selanjutnya. Jika kriteria tersebut tidak terpenuhi, maka akan mengakibatkan kesulitan dan miskonsepsi pada siswa. Contohya konsep katalis yang disajikan pada buku teks pelajaran SMA memberikan kontribusi miskonsepsi siswa karena konsep yang disajikan tidak benar secara keilmuan (Justi, 2002).

Penelitian serupa juga diungkapkan pada penelitian yang dilakukan oleh Natalia (2019), Rusianti (2019), Wulandari (2019), dan Wibowo dalam Winarni (2010) ditemukan kebanyakan buku teks pelajaran kimia SMA di Indonesia memiliki kelemahan yaitu kurang atau tidak adanya penjelasan pendahuluan yang mengantarkan siswa untuk memahami isi suatu materi. Dengan adanya kelemahan tersebut, maka kemungkinan terjadi kesalahan-kesalahan dalam contoh-contoh dan penjelasan yang diberikan. Selain itu buku teks pelajaran kimia perlu memuat penanaman nilai sehingga sejalan dengan tujuan kurikulum 2013. Dengan adanya penanaman nilai menunjang tercapainya tujuan kurikulum 2013 berbasis pendidikan karakter.

Berdasarkan uraian tersebut, maka penulis perlu untuk mengkaji tentang "Analisis Materi Ajar Konsep Laju Reaksi Pada Buku Teks Kimia SMA/MA" agar potensi kesalahan konsep atau miskonsepsi yang ditimbulkan oleh buku teks dapat diminimalisir.

\section{METODOLOGI PENELITIAN}

Penelitian ini menggunakan metode penelitian deskriptif yang bertujuan untuk mendeskripsikan fenomena-fenomena yang ada. Hal yang dideskripsikan dalam penelitian ini adalah hasil analisis konsep materi Laju Reaksi dalam buku 
kimia SMA/MA kelas XI. Waktu pengumpulan data dimulai pada bulan Februari 2019 dan objek penelitian adalah dua buku SMA/MA berdasarkan kurikulum 2013 yang disajikan pada tabel 1.

Tabel 1. Buku Teks Laju Reaksi

\begin{tabular}{llllcc}
\hline No. & \multicolumn{1}{c}{ Judul } & \multicolumn{1}{c}{ Penulis } & Penerbit & $\begin{array}{c}\text { Tempat dan } \\
\text { Tahun Terbit }\end{array}$ & $\begin{array}{c}\text { Kode } \\
\text { Buku }\end{array}$ \\
\hline & $\begin{array}{l}\text { Buku Teks Kimia } \\
\text { untuk SMA/MA }\end{array}$ & $\begin{array}{l}\text { Michael Purba } \\
\text { dan Eti }\end{array}$ & Erlangga & Surakarta, 2013 & A \\
$\begin{array}{l}\text { Kelas XI } \\
\text { Buku Teks Kimia } \\
\text { untuk SMA/MA }\end{array}$ & $\begin{array}{l}\text { Sarwiyati } \\
\text { Suparmin, } \\
\text { Kelas XI }\end{array}$ & dkk. & Mediatama & Jakarta, 2016 & B \\
\hline & & & & \\
\hline
\end{tabular}

A dan buku teks B yang dikumpulkan melalui lembar observasi berupa teks asli, teks dasar, dan teks asli yang berpotensi kesalahan konsep (miskonsepsi). Langkah-langkah pengumpulan data yaitu, sebagai berikut:

Tabel 2. Langkah-Langkah Pengumpulan Data

\begin{tabular}{|c|c|c|}
\hline $\begin{array}{c}\text { Data yang } \\
\text { Dikumpulkan }\end{array}$ & Teknik Pengumpulan Data & Instrumen \\
\hline $\begin{array}{l}\text { - Teks Asli } \\
\text { - Teks Dasar }\end{array}$ & $\begin{array}{l}\text { 1. Teks asli diambil dari masing- } \\
\text { masing materi ajar dengan cara } \\
\text { discan menggunakan printer dan } \\
\text { diketik pada program microsoft } \\
\text { word } \\
\text { 2. Teks asli yang discan atau } \\
\text { diketik berupa konsep materi laju } \\
\text { reaksi. } \\
\text { 3. Teks asli dimasukan kedalam } \\
\text { tabel pembentukan teks dasar, dalam } \\
\text { pembentukkan teks dasar dilakukan } \\
\text { proses penghalusan melalui } \\
\text { penghapusan dan penyisipan kata } \\
\text { 4. Teks asli diidentifikasi dengan } \\
\text { menggunakan tabel identifikasi pada } \\
\text { tabel } 6 \text { dan } 7 \text {. }\end{array}$ & $\begin{array}{l}\text { Lembar observasi } \\
\text { dalam bentuk tabel } \\
\text { identifikasi } \\
\text { relevansi teks asli } \\
\text { dengan label }\end{array}$ \\
\hline $\begin{array}{l}\text { - } \text { Teks asli } \\
\text { - Teks asli yang } \\
\text { berpotensi } \\
\text { kesalahan } \\
\text { konsep }\end{array}$ & $\begin{array}{l}\text { 1. Teks asli (konsep laju reaksi } \\
\text { dan contoh soal) pada materi laju } \\
\text { reaksi ditelaah secara cermat. } \\
\text { 2. Setelah ditelaah secara } \\
\text { keseluruhan pada teks asli dapat } \\
\text { ditemukan proposisi yang berpotensi } \\
\text { kesalahan konsep. } \\
\text { 3. Teks asli yang berpotensi } \\
\text { kesalahan konsep discan atau } \\
\text { diketik pada program microsoft } \\
\text { word }\end{array}$ & $\begin{array}{l}\text { Lembar observasi } \\
\text { dalam bentuk tabel } \\
\text { identifikasi } \\
\text { proposisi yang } \\
\text { berpotensi } \\
\text { kesalahan konsep } \\
\text { (miskonsepsi) }\end{array}$ \\
\hline
\end{tabular}




\begin{tabular}{ccc}
\hline $\begin{array}{c}\text { Data yang } \\
\text { Dikumpulkan }\end{array}$ & \multicolumn{1}{c}{ Teknik Pengumpulan Data } & Instrumen \\
\hline & 4. & Proposisi yang berpotensi \\
& kesalahan konsep & \\
& diidentifikasidengan menggunakan \\
& tabel identifikasi pada tabel 8 yang \\
& memuat konsepsi peneliti. \\
\hline
\end{tabular}

Data yang diperoleh pada lembar observasi dianalisis dengan langkahlangkah sebagai berikut:

Tabel 3. Langkah-Langkah Analisis Data

Data yang dianalisis

Teknik Analisis Data

- Teks Dasar

1. Teks dasar yang diperoleh dimasukkan ke dalam tabel penurunan proposisi mikro dan makro yang melalui proses penghapusan, generalisasi, dan konstruksi dengan menyalin (copy-paste) pada program microsoft word

2. Pada proses penghapusan dilakukan untuk menghilangkan kata-kata yang tidak diperlukan sehingga akan menghasilkan proposisi mikro dan makro

3. Pada proses generalisasi dapat diturunkan dari proposisi tertentu sehingga dihasilkan proposisi makro yang bersifat umum

4. Pada proses konstruksi dapat dihasilkan proposisi baru, yaitu proposisi makro dibangun dari beberapa proposisi mikro

5. Label konsep (proposisi makro) yang didapatkan disesuaikan terhadap kurikulum 2013

6. Proposisi makro yang dihasilkan akan dilakukan pemetaan ke dalam struktur makro wacana

Teks asli yang
berpotensi
kesalahan konsep
(miskonsepsi)

1. Teks asli yang berpotensi kesalahan konsep dilakukan analisis dengan cara memberikan konsepsi peneliti, menunjukkan teks yang berpotensi kesalahan konsep, dan alasan penentuan teks yang berpotensi kesalahan konsep (miskonsepsi)

\section{HASIL PENELITIAN DAN PEMBAHASAN}

Konsep laju reaksi dibahas pada Bab 3, Halaman 124 - Halaman 154. Analisis konsep dilakukan pada keseluruhan materi laju reaksi. Berikut ini akan dijelaskan mengenai hasil dan pembahasan dari analisis konsep yang meliputi relevansi antara teks asli dengan label konsep serta jenis pengetahuan pada buku teks A. 
Tabel 4. Cuplikan Hasil Identifikasi Label Konsep dan Jenis Pengetahuan Berdasarkan Teks Dasar pada Buku Teks A

\begin{tabular}{cllc}
\hline No. & \multicolumn{1}{c}{ Teks Dasar } & $\begin{array}{c}\text { Label } \\
\text { Konsep }\end{array}$ & Jenis Pengetahuan \\
\hline 1. & $\begin{array}{l}\text { Laju reaksi dapat dinyatakan sebagai } \\
\text { laju berkurangnya pereaksi atau laju } \\
\text { terbentuknya produk persatuan waktu. }\end{array}$ & $\begin{array}{l}\text { Pengertian } \\
\text { Laju Reaksi }\end{array}$ & Konseptual \\
\hline
\end{tabular}

Label konsep yang pertama pada tabel 4 yaitu pengertian laju reaksi memiliki jenis pengetahuan konseptual. Label konsep pengertian laju reaksi memiliki jenis pengetahuan konseptual dengan ciri-ciri jenis pengetahuan konseptualnya adalah ditampilkan pengetahuan tentang prinsip dan generalisasi berupa pengertian tentang laju reaksi.

Konsep laju reaksi dibahas pada Bab 3, Halaman 71 - Halaman 92. Analisis konsep dilakukan pada keseluruhan materi laju reaksi. Berikut ini akan dijelaskan mengenai hasil dan pembahasan dari analisis konsep yang meliputi relevansi antara teks asli dengan label konsep serta jenis pengetahuan pada buku B

Tabel 5. Cuplikan Hasil Identifikasi Label Konsep dan Jenis Pengetahuan Berdasarkan Teks Dasar pada Buku Teks B

\begin{tabular}{cllc}
\hline No. & \multicolumn{1}{c}{ Teks Dasar } & Label Konsep & Jenis Pengetahuan \\
\hline 1. & Salah satu contoh laju reaksi yang & Laju reaksi & Faktual \\
& sering terjadi adalah melarutkan & dalam & \\
& gula dalam air panas. Contoh & kehidupan & \\
lainnva adalah pada proses & sehari-hari & \\
pematangan buah.buahan. Supava & & \\
buah-buahan yang sudah dipanen & & \\
cepat matang yaitu dengan & & \\
& menambah karbit dalam buah- & \\
buahan tersebut. Karbit berperan & & \\
& sebagai katalis untuk buah-buahan \\
& karena dengan adanya karbit, & \\
& buah-buahan bisa cepat matang & \\
& sebelum waktunya. & \\
\hline
\end{tabular}

Label konsep yang kedua pada tabel 5 yaitu laju reaks dalam kehidupan sehari-hari yaitu memiliki jenis pengetahuan faktual. Label konsep laju reaksi dalam kehidupan sehari-hari memiliki jenis pengetahuan faktual dengan ciri-ciri ditampilkan informasi berupa contoh laju reaksi dalam kehidupan sehari-hari yaitu berupa pelarutan gula dalam air panas dan penggunaan karbit sebagai katalis untuk mempercepat pematangan buah.

Perbandingan label konsep buku teks A dan buku teks B dapat dicermati dengan tabel 6 berikut ini. 
Tabel 6. Perbandingan Label Konsep Buku Teks A dan Buku Teks B

\begin{tabular}{|c|c|c|c|c|c|}
\hline No & Label Konsep & $\begin{array}{c}\text { Buku } \\
\text { A }\end{array}$ & Halaman & $\begin{array}{c}\text { Buku } \\
\text { B }\end{array}$ & Halaman \\
\hline 1. & Pengertian Laju & $\sqrt{ }$ & 100 & & \\
\hline 2. & Pengertian reaksi kimia & $\sqrt{ }$ & 101 & & \\
\hline 3. & Pengertian laju reaksi & $\sqrt{ }$ & 101 & $\sqrt{ }$ & 123 \\
\hline 4. & Pengertian molaritas & & & $\sqrt{ }$ & 125 \\
\hline 5. & Rumus polaritas & & & $\sqrt{ }$ & 125 \\
\hline 6. & Penentuan laju reaksi & $\sqrt{ }$ & 102 & & \\
\hline 7. & Rumus laju reaksi & $\sqrt{ }$ & 106 & $\sqrt{ }$ & 126 \\
\hline 8. & $\begin{array}{l}\text { Pengaruh Luas } \\
\text { permukaan }\end{array}$ & $\sqrt{ }$ & 107 & $\sqrt{ }$ & 130 \\
\hline 9. & $\begin{array}{l}\text { Pengaruh Konsentrasi } \\
\text { pereaksi }\end{array}$ & $\sqrt{ }$ & 108 & $\sqrt{ }$ & 129 \\
\hline 10. & Pengaruh Tekanan & $\sqrt{ }$ & 109 & & \\
\hline 11. & Pengaruh Suhu & $\sqrt{ }$ & 110 & $\sqrt{ }$ & 130 \\
\hline 12. & Pengaruh Katalis & $\sqrt{ }$ & 111 & $\sqrt{ }$ & 131 \\
\hline 13. & Katalis homogen & $\sqrt{ }$ & 112 & & \\
\hline 14. & Katalis heterogen & $\sqrt{ }$ & 112 & & \\
\hline 15. & $\begin{array}{l}\text { Bentuk persamaan laju } \\
\text { reaksi/ Hukum laju } \\
\text { reaksi }\end{array}$ & $\sqrt{ }$ & 113 & $\sqrt{ }$ & 132 \\
\hline 16. & Tetapan laju reaksi & $\sqrt{ }$ & 113 & $\sqrt{ }$ & 133 \\
\hline 17. & Orde reaksi & $\sqrt{ }$ & 114 & $\sqrt{ }$ & 133 \\
\hline 18. & $\begin{array}{l}\text { Orde reaksi } \\
\text { keseluruhan/ orde } \\
\text { reaksi total }\end{array}$ & $\sqrt{ }$ & 114 & $\sqrt{ }$ & 133 \\
\hline 19. & Orde reaksi 0 & $\sqrt{ }$ & 115 & $\sqrt{ }$ & 134 \\
\hline 20. & Orde reaksi 1 & $\sqrt{ }$ & 115 & $\sqrt{ }$ & 134 \\
\hline 21. & Orde reaksi 2 & $\sqrt{ }$ & 116 & $\sqrt{ }$ & 135 \\
\hline 22. & Orde rekasi -2 & & & $\sqrt{ }$ & 135 \\
\hline 23. & Orde reaksi $1 / 2$ & & & $\sqrt{ }$ & 136 \\
\hline 24. & $\begin{array}{l}\text { Penentuan persamaan } \\
\text { laju }\end{array}$ & $\sqrt{ }$ & 116 & $\sqrt{ }$ & 136 \\
\hline 25. & Tumbukan efektif & $\sqrt{ }$ & 117 & $\sqrt{ }$ & 127 \\
\hline 26. & Energi aktivasi & $\sqrt{ }$ & 118 & $\sqrt{ }$ & 129 \\
\hline 27. & $\begin{array}{l}\text { Orientasi/ arah partikel } \\
\text { yang bertumbukan }\end{array}$ & $\sqrt{ }$ & 117 & $\sqrt{ }$ & 128 \\
\hline 28. & $\begin{array}{l}\text { Pengaruh konsentrasi } \\
\text { dan luas permukaan } \\
\text { (Teori tumbukan) }\end{array}$ & $\sqrt{ }$ & 118 & & \\
\hline 29. & $\begin{array}{l}\text { Pengaruh suhu (Teori } \\
\text { tumbukan) }\end{array}$ & $\sqrt{ }$ & 119 & & \\
\hline 30. & $\begin{array}{l}\text { Pengaruh katalis (Teori } \\
\text { tumbukan) }\end{array}$ & $\sqrt{ }$ & 120 & & \\
\hline
\end{tabular}




\begin{tabular}{lrcccc}
\hline No & Label Konsep & $\begin{array}{c}\text { Buku } \\
\text { A }\end{array}$ & Halaman & $\begin{array}{c}\text { Buku } \\
\text { B }\end{array}$ & Halaman \\
\hline 31. & Sifat-sifat katalis & $\sqrt{ }$ & 121 & & \\
\hline
\end{tabular}

Keterangan:

$\square$ : Label konsep yang sama terdapat pada buku teks A dan buku teks B : Label konsep yang hanya terdapat pada buku teks A

: Label konsep yang hanya terdapat pada buku teks B

Label konsep termokimia yang terdapat pada buku teks A maupun buku teks B dianalisis kesesuaian dengan silabus mata pelajaran kimia kurikulum 2013. Hasil analisis kesesuaian ditampilkan pada tabel 7.

Tabel 7. Kesesuaian Label Konsep Buku Teks A dan Buku Teks B Terhadap Kurikulum 2013

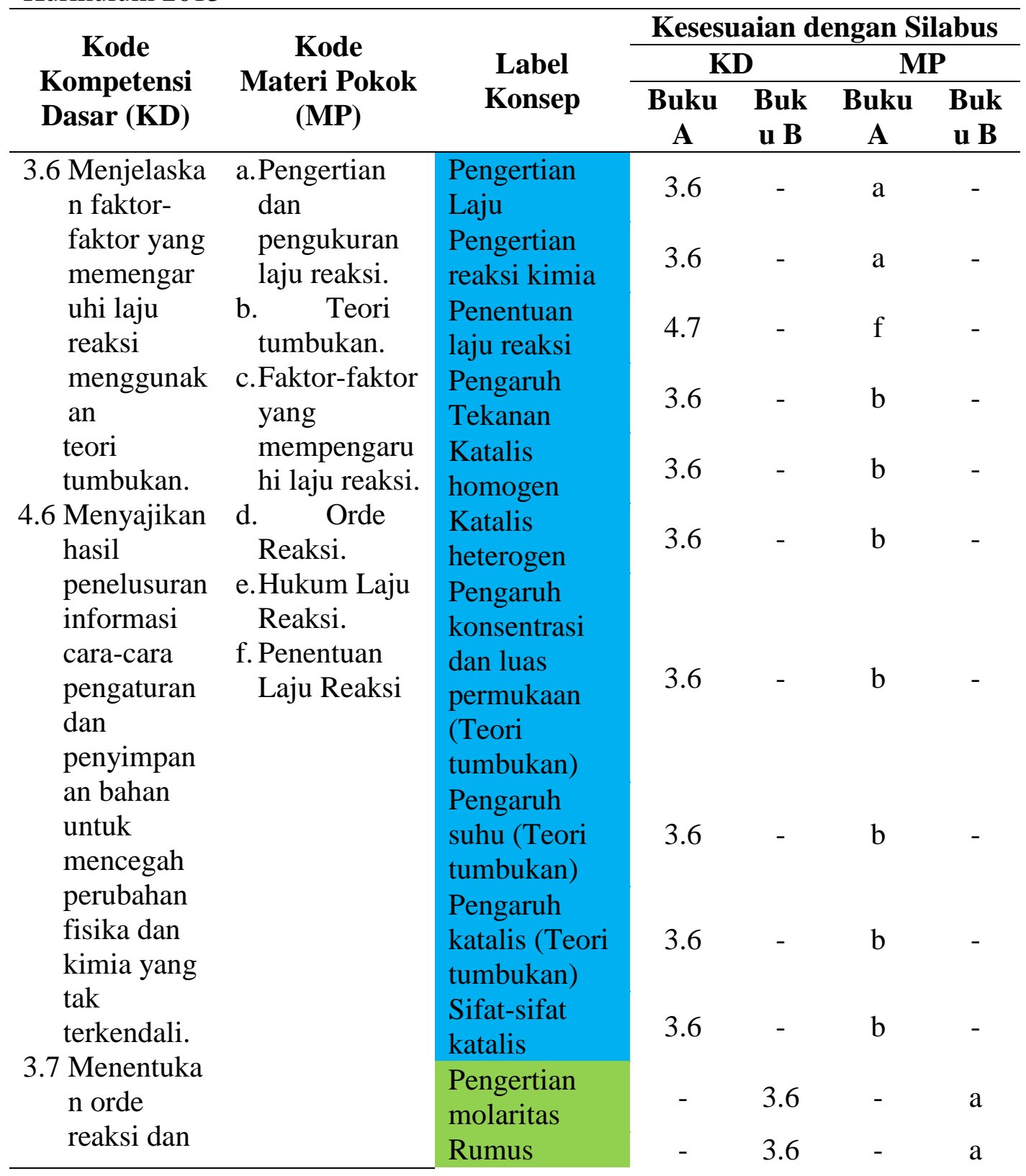




\begin{tabular}{|c|c|c|c|c|c|c|}
\hline \multirow{3}{*}{$\begin{array}{c}\text { Kode } \\
\text { Kompetensi } \\
\text { Dasar (KD) }\end{array}$} & \multirow{3}{*}{$\begin{array}{c}\text { Kode } \\
\text { Materi Pokok } \\
\text { (MP) }\end{array}$} & \multirow{3}{*}{$\begin{array}{c}\text { Label } \\
\text { Konsep }\end{array}$} & \multicolumn{4}{|c|}{ Kesesuaian dengan Silabus } \\
\hline & & & \multicolumn{2}{|c|}{ KD } & \multicolumn{2}{|c|}{ MP } \\
\hline & & & $\begin{array}{c}\text { Buku } \\
\text { A }\end{array}$ & $\begin{array}{l}\text { Buk } \\
\text { u B }\end{array}$ & $\begin{array}{c}\text { Buku } \\
\text { A }\end{array}$ & $\begin{array}{c}\text { Buk } \\
\text { u B }\end{array}$ \\
\hline tetapan laju & & molaritas & & & & \\
\hline reaksi & & Orde rekasi - & - & - & - & - \\
\hline $\begin{array}{l}\text { berdasarka } \\
\text { n data hasil }\end{array}$ & & $\begin{array}{l}2 \\
\text { Orde reaksi }\end{array}$ & & & & \\
\hline percobaan. & & & - & - & - & - \\
\hline $\begin{array}{l}\text { 4.7 Merancang, } \\
\text { melakukan, }\end{array}$ & & $\begin{array}{l}\text { Pengertian } \\
\text { laju reaksi }\end{array}$ & 3.6 & 3.6 & $\mathrm{a}$ & $\mathrm{a}$ \\
\hline $\begin{array}{l}\text { dan } \\
\text { menyimpul }\end{array}$ & & $\begin{array}{l}\text { Rumus laju } \\
\text { reaksi }\end{array}$ & 3.6 & 3.6 & $\mathrm{a}$ & a \\
\hline kan serta & & Pengaruh & 4.7 & 4.7 & $\mathrm{c}$ & $\mathrm{c}$ \\
\hline $\begin{array}{l}\text { menyajikan } \\
\text { hasil }\end{array}$ & & $\begin{array}{l}\text { Luas } \\
\text { permukaan }\end{array}$ & & & & \\
\hline percobaan & & Pengaruh & 4.7 & 4.7 & $\mathrm{c}$ & $\mathrm{c}$ \\
\hline $\begin{array}{l}\text { faktor- } \\
\text { faktor yang }\end{array}$ & & $\begin{array}{l}\text { Konsentrasi } \\
\text { pereaksi }\end{array}$ & & & & \\
\hline mempengar & & Pengaruh & 4.7 & 4.7 & $\mathrm{c}$ & $\mathrm{c}$ \\
\hline ui laju & & Suhu & & & & \\
\hline reaksi dan. & & Pengaruh & 4.7 & 4.7 & $\mathrm{c}$ & $\mathrm{c}$ \\
\hline orde reaksi & & Katalis & & & & \\
\hline & & $\begin{array}{l}\text { Bentuk } \\
\text { nersamaan }\end{array}$ & 3.7 & 3.7 & $\mathrm{e}$ & $\mathrm{e}$ \\
\hline & & $\begin{array}{l}\text { persamaan } \\
\text { laju reaksi/ }\end{array}$ & & & & \\
\hline & & $\begin{array}{l}\text { Hukum laju } \\
\text { reaksi }\end{array}$ & & & & \\
\hline & & $\begin{array}{l}\text { Tetapan laju } \\
\text { reaksi }\end{array}$ & 3.7 & 3.7 & $\mathrm{e}$ & $\mathrm{e}$ \\
\hline & & $\begin{array}{l}\text { Pengertian } \\
\text { orde reaksi }\end{array}$ & 3.7 & 3.7 & d & $\mathrm{d}$ \\
\hline & & Orde reaksi & 3.7 & 3.7 & d & $\mathrm{d}$ \\
\hline & & $\begin{array}{l}\text { keseluruhan/ } \\
\text { orde reaksi } \\
\text { total }\end{array}$ & & & & \\
\hline & & Orde reaksi 0 & 3.7 & 3.7 & d & d \\
\hline & & Orde reaksi 1 & 3.7 & 3.7 & $d$ & $\mathrm{~d}$ \\
\hline & & Orde reaksi 2 & 3.7 & 3.7 & d & $\mathrm{d}$ \\
\hline & & $\begin{array}{l}\text { Penentuan } \\
\text { persamaan } \\
\text { laju }\end{array}$ & 3.7 & 3.7 & $\mathrm{e}$ & e \\
\hline & & $\begin{array}{l}\text { Tumbukan } \\
\text { efektif }\end{array}$ & 3.6 & 3.6 & b & b \\
\hline & & $\begin{array}{l}\text { Energi } \\
\text { aktivasi }\end{array}$ & 3.6 & 3.6 & b & b \\
\hline
\end{tabular}




\begin{tabular}{|c|c|c|c|c|c|c|}
\hline \multirow{4}{*}{$\begin{array}{c}\text { Kode } \\
\text { Kompetensi } \\
\text { Dasar (KD) }\end{array}$} & \multirow{4}{*}{$\begin{array}{c}\text { Kode } \\
\text { Materi Pokok } \\
\text { (MP) }\end{array}$} & \multirow{3}{*}{$\begin{array}{c}\text { Label } \\
\text { Konsep }\end{array}$} & \multicolumn{4}{|c|}{ Kesesuaian dengan Silabus } \\
\hline & & & \multicolumn{2}{|c|}{ KD } & \multicolumn{2}{|c|}{ MP } \\
\hline & & & Buku & $\begin{array}{c}\text { Buk } \\
\text { u B }\end{array}$ & Buku & $\begin{array}{c}\text { Buk } \\
\text { u B }\end{array}$ \\
\hline & & $\begin{array}{l}\text { Orientasi/ } \\
\text { arah partikel } \\
\text { yang } \\
\text { bertumbukan }\end{array}$ & 3.6 & 3.6 & $\mathrm{~b}$ & $\mathrm{~b}$ \\
\hline
\end{tabular}

Keterangan:

$\square$ : Label konsep yang sama terdapat pada buku teks A dan buku teks B

$\square$ : Label konsep yang hanya terdapat pada buku teks A

$\square$ : Label konsep yang hanya terdapat pada buku teks B

Tanda (-) : Tidak ada label konsep

Berdasarkan Tabel 7 di atas menunjukkan bahwa kesesuaian label konsep dengan kurikulum 2013, yang terbagi menjadi tiga warna diantaranya orange yaitu warna yang menunjukkan bahwa label konsep yang sama terdapat pada buku teks A dan buku teks B yang berjumlah 17 label konsep. Setelah dianalisis, ternyata label konsep yang ditandai dengan warna orange sudah sesuai dengan KD dan MP pada silabus kurikulum 2013. Contohnya pada label konsep pengaruh luas permukaan yang sesuai dengan KD 4.7 yaitu merancang, melakukan, dan menyimpulkan serta menyajikan hasil percobaan faktor-faktor yang mempengarui laju reaksi dan orde reaksi. Label Konsep ini juga termasuk ke dalam materi pokok (MP) c yaitu faktor-faktor yang mempengaruhi laju reaksi..

Warna yang kedua adalah warna biru yang menunjukkan bahwa label konsep terdapat pada buku teks A yang berjumlah 10 label konsep dan semua label konsep sesuai dengan silabus kurikulum 2013. Contohnya pada label pengaruh katalis (teori tumbukan) yang sesuai dengan KD 3.6 yaitu menjelaskan faktor-faktor yang memengaruhi laju reaksi menggunakan teori tumbukan. Label konsep ini merujuk pada materi pokok (MP) b teori tumbukan..

Warna yang ketiga adalah warna hijau yang menunjukkan bahwa label konsep terdapat pada buku teks B yang berjumlah 4 label konsep. Terdapat 2 label konsep yang tidak sesuai dengan silabus kurikulum 2013 yaitu orde reaksi -2 dan orde reaksi $1 / 2$ dan 2 label konsep yang sesuai dengan silabus kurikulum 2013 yaitu pengertian molaritas dan rumus molaritas.

Hasil analisis dua buku yang telah dilakukan bahwa label konsep yang sesuai dengan silabus K-13 lebih banyak terdapat pada buku teks A dibandingkan dengan buku teks B. Proposisi yang berpotensi kesalahan konsep lebih banyak terdapat pada buku B dibandingkan dengan buku A. Oleh karena itu, buku A dapat digunakan dalam proses pembelajaran.

Susunan makro wacana laju reaksi pada buku teks A pembahasan konsep dimensi elaborasi mencapai level 4 dan dimensi progresi terdapat 4 konsep pada level 2. Hasil analisis diperoleh empat buah makro utama dan dua puluh tujuh, makro bawahan yaitu sebagai berikut:

a. Empat buah makro utama, yaitu:

P-I = Konsep Laju Reaksi

P-II = Faktor-faktor yang memengaruhi laju reaksi 


$$
\begin{array}{ll}
\text { P-III } & =\text { Persamaan Laju reaksi } \\
\text { P-IV } & =\text { Teori Tumbukan }
\end{array}
$$

b. Dua puluh tujuh makro bawahan, yaitu:

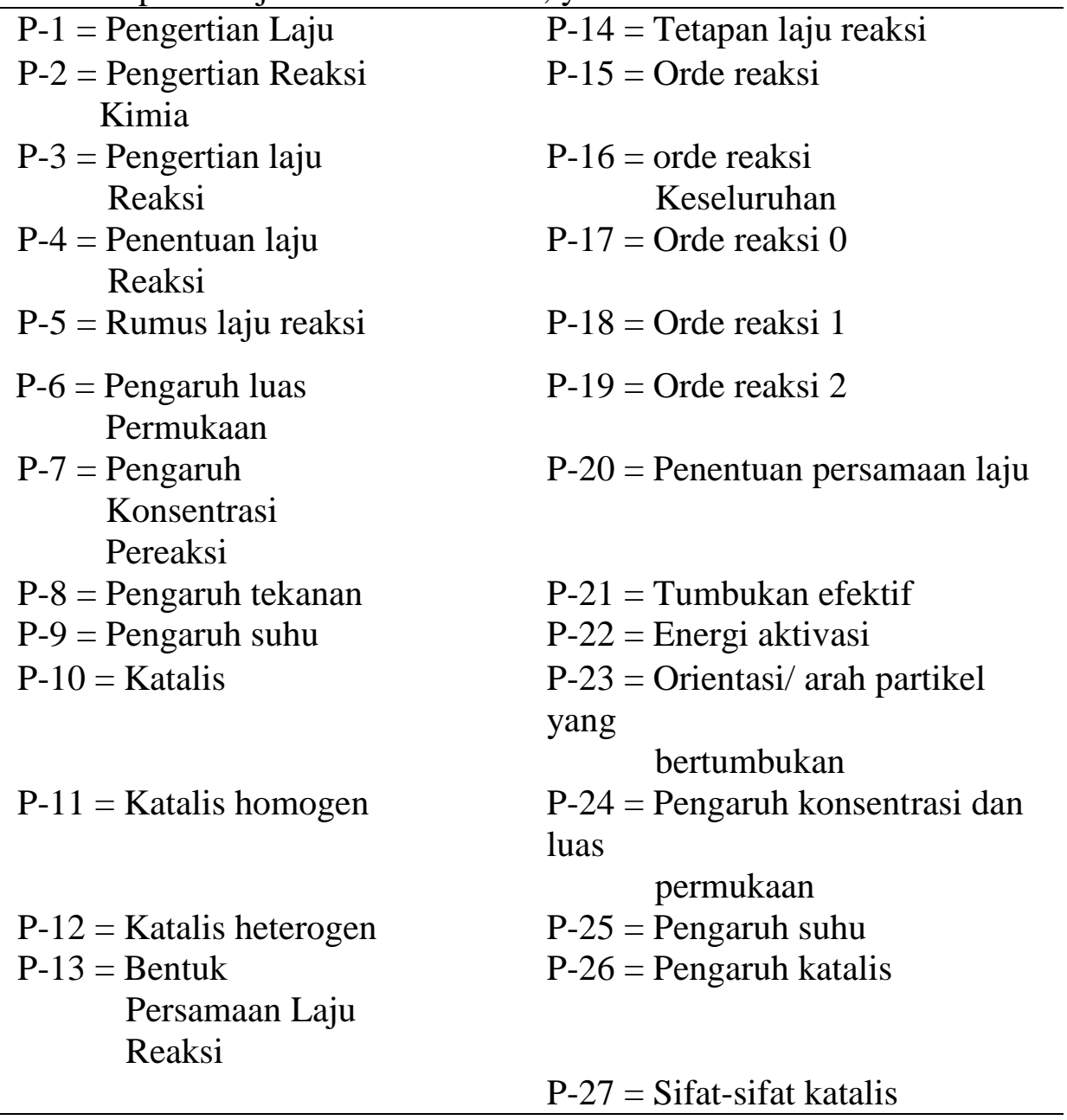

Susunan makro wacana laju reaksi pada buku teks B pembahasan konsep dimensi elaborasi mencapai level 4 dan dimensi progresi terdapat 5 konsep pada level 2. Hasil analisis diperoleh Lima buah makro utama dan dua puluh satu makro bawahan yaitu sebagai berikut:

a. Lima buah makro utama, yaitu:

$$
\begin{array}{ll}
\text { P-I } & \text { = Konsep Laju Reaksi } \\
\text { P-II } & =\text { Teori tumbukan } \\
\text { P-III } & =\text { Faktor penentu laju reaksi } \\
\text { P-IV } & \text { = Persamaan laju reaksi } \\
\text { P-V } & \text { = Laju reaksi dalam kehidupan sehari-hari }
\end{array}
$$

\begin{tabular}{|c|c|}
\hline P-1 = Pengertian Laju Reaksi & $\mathrm{P}-12=\underset{\text { Reaksi }}{\text { Hukum laju }}$ \\
\hline P-2 = Pengertian Molaritas & $\begin{aligned} & \mathrm{P}-13= \text { Tetapan laju } \\
& \text { reaksi }\end{aligned}$ \\
\hline
\end{tabular}

b. Dua puluh satu makro bawahan, yaitu: 


$$
\begin{aligned}
& \text { P-3 = Rumus Molaritas } \\
& \mathrm{P}-14=\text { Orde reaksi } \\
& \text { P-4 = Rumus laju reaksi } \\
& \mathrm{P}-15=\text { Orde reaksi total } \\
& \text { P-5 = Tumbukan efektif } \\
& \mathrm{P}-16=\text { Orde reaksi } 0 \\
& \text { P-6 = Orientasi atau arah } \\
& \mathrm{P}-17=\text { Orde reaksi } 1 \\
& \text { partikel yang Bertumbukan } \\
& \mathrm{P}-7=\text { energi aktivasi } \\
& \mathrm{P}-18=\text { Orde reaksi } 2 \\
& \text { P-8 = Pengaruh konsentrasi } \\
& \text { Pereaksi } \\
& \text { P-9 = Pengaruh luas } \\
& \text { permukaan } \\
& \mathrm{P}-10=\text { Pengaruh suhu } \\
& \mathrm{P}-11=\text { Pengaruh Katalis } \\
& \text { P-19 = Orde reaksi nol -2 } \\
& \mathrm{P}-20=\text { Orde reaksi } 1 / 2 \\
& \text { P-21 = Penentuan laju reaksi }
\end{aligned}
$$

Proposisi yang berpotensi miskonsepsi (Buku Teks A) yaitu terdapat pada katalis yaitu kalimat tidak dikonsumsi atau tidak dihabiskan tidak memiliki makna yang jelas dan kurang tetap sehingga bisa menyebabkan siswa mengalami miskonsepsi seperti pada gambar berikut:

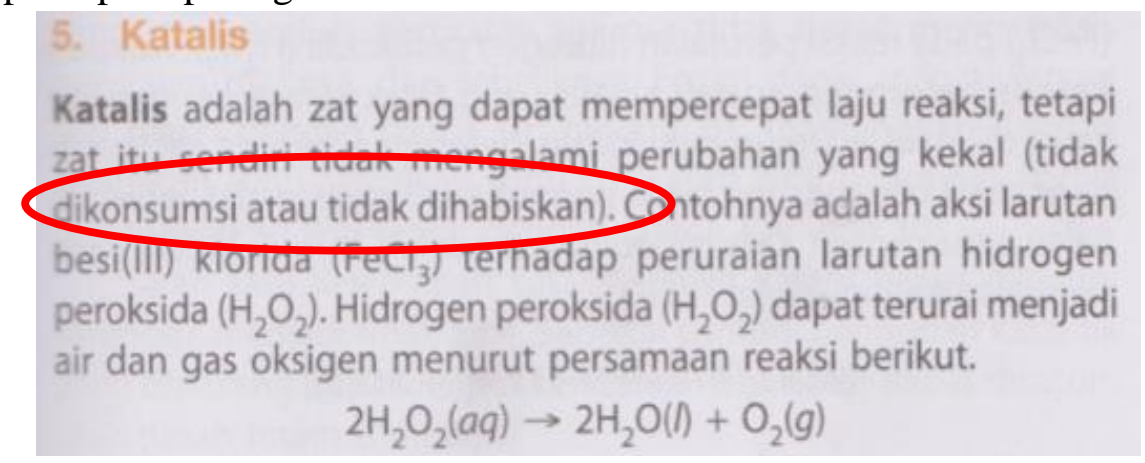

Gambar 9. Proposisi yang berpotensi kesalahan konsep 1

Pada tahun 1902 Ostwald mendefinisikan katalis adalah zat yang dapat mempercepat laju reaksi, tetapi zat itu tidak mengalami perubahan secara permanen sehingga zat tersebut dapat diperoleh kembali pada akhir reaksi.

Proposisi yang berpotensi miskonsepsi yang pertama yaitu terdapat pada rumus molaritas yaitu gram dituliskan pada rumus seperti yang disajikan pada rumus berikut:

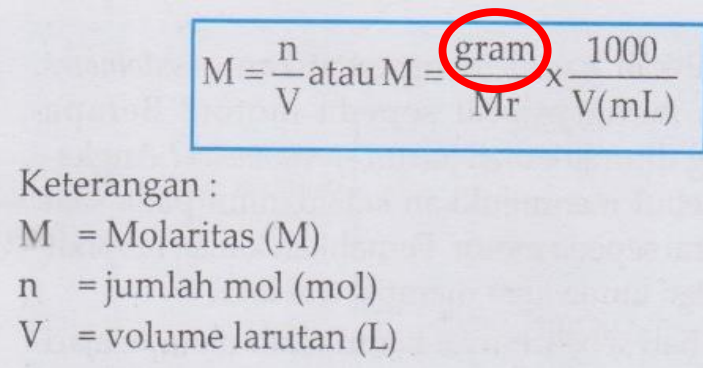

Gambar 11. Proposisi yang berpotensi kesalahan konsep 3 
Sesuatu yang dapat diukur dan hasilnya dapat dinyatakan dengan nilai dan satuan disebut Besaran Fisika. Satuan adalah sesuatu yang menyatakan hasil pengukuran. Satuan gram (g) tidak tepat jika dituliskan dalam rumus karena gram (g) menyatakan hasil pengukuran yang merupakan besaran massa dalam sistem internasional atau disingkat SI dan sistem metriks kecil atau CGS (Centimeter Gram Second), untuk menghindari miskonsepsi maka penulisan yang tepat pada rumus adalah besaran seperti berikut:

$$
\mathrm{M}=\frac{\text { massa }}{\text { massa molar }} \times \frac{1000}{\mathrm{~V}(\mathrm{~mL})}
$$

\section{SIMPULAN}

Berdasarkan hasil penelitian yang diperoleh, maka dapat disimpulkan bahwa Label konsep keseluruhan buku A dan Buku B yang dianalisis berjumlah 48 label konsep. Label Konsep yang terdapat pada buku teks A (tidak terdapat dalam buku teks B) yang sesuai dengan kurikulum 2013 berjumlah 10 label konsep dan label konsep yang terdapat pada buku teks B (tidak terdapat dalam buku teks A) yang sesuai dengan kurikulum 2013 berjumlah 2 label konsep.

Susunan makro wacana laju reaksi pada buku teks A pembahasan konsep dimensi elaborasi mencapai level 4 dan dimensi progresi terdapat 4 konsep pada level 2. Susunan makro wacana laju reaksi pada buku teks B pembahasan konsep dimensi elaborasi mencapai level 4 dan dimensi progresi terdapat 5 konsep pada level 2.

Proposisi yang berpotensi kesalahan konsep pada buku teks A yaitu penjelasan katalis dan tetapan laju reaksi $(\mathrm{k})$. Proposisi yang berpotensi kesalahan konsep pada buku teks B yaitu pada rumus molaritas, penulisan koefisien reaksi, penjelasan pengaruh luas permukaan, penjelasan grafik orde reaksi 0 , orde reaksi 1 , orde reaksi 2 , orde reaksi -2 , orde reaksi $1 \frac{1}{2}$.

\section{DAFTAR PUSTAKA}

Anggi, A. 2016. Pengembangan Courseware Multimedia Interaktif pada Sub Materi Terhadap Laju Reaksi untuk Siswa SMA. Laporan Penelitian, tidak diterbitkan. UPI.

Anwar, Saeful. 2014. Pengembangan Bahan Ajar. Bandung: Jurusan Pendidikan Kimia FPMIPA. tidak diterbitkan. Universitas Pendidikan Indonesia.

Arifin. 2008. Pembuatan Hiperteks Akademik Pada Materi Kajian Kecepatan Reaksi dan Pemanfaatannya Sebagai Media Pembelajaran kimia di SMA. Laporan Penelitian, tidak diterbitkan. UPR.

Arikunto, S. 2010. Prosedur Penelitian suatu Pendekatan Praktik. Jakarta: PT. Rineka Cipta.

Berg,Van Den. 1991. Miskonsepsi Fisika Remediasi. Salatiga: Universitas Kristen Satya Wacana.

Bowyer, Gabrielle. 2009. Teacher's handbook of Chemistry. Delhi: Global Media

Brown, Lawrense, dan Holme, Thomas A. 2011. Chemistry for Engineering Students. USA: Cengage Learning. 
Chang, Raymond. 2003. Kimia Dasar. Jakarta: Erlanga.

Darmana, Ayi, Permanasari, Anna Sauri, Sofyan Sunarya, Yayan. 2013. Pandangan Siswa terhadap Internalisasi Nilai Tauhid melalui Materi Termokimia. Prosiding Semirata FMIPA Universitas Lampung, 2013.

Gagne, RM dan RJ Briggs. 1997. Condition of Learning (Kondisi Belajar). New York: Holt Rinehard and Winston, Internasional Journal.

Justi, R. 2002, Teaching and Learning Chemical Kinetics, in Gilbert J. K., De Jong O, Justi R., Treagust D. F.dan Van Driel J. H. (ed.), Chemical Education: Towards Research based Practice, Netherlands: Springer, pp. 293-315.

Kaya, E. E dan Geban, Omer. 2012. Facilitating Conceptual Change in Rate of Reaction Concepts Using Conceptual Change Oriented Instruction. Journal Education and Science 2012, Vol. 37, No 163.

Kırık, T.Z dan Boz, Yezdan. 2012. Cooperative Learning Instruction For Conceptual Change In The Concepts Of Chemical Kinetics. RSC. Pract, 2012, 13, 221-236.

Kolomuc, Ali dan Seher Tekin. 2011. Chemistry Teachers' Misconceptions Concerning Concept of Chemical Reaction Rate. Eurasian Journal. Phys.Chem. Educ. 3(2): 84-101.

Kuswana, W.S. 2012. Taksonomi Kognitif (Perkembangan Ragam Berpikir). Bandung: PT Remaja Rosdakarya.

Majid, Abdul., dan Chaerul R. 2014. Pendekatan Ilmiah dalam Implementasi Kurikulum 2013. Bandung: PT. Remaja Rosdakarya.

Muslich, Mansur. 2010. Text Book Writing. Jakarta: Ar-Ruzz Media.

Natalia, D., Fatah, A.H. and Mulawi 2019. Analisis Kesesuaian Konsep Struktur Atom Pada Buku Kimia Kelas X SMA/MA Terhadap Silabus Kurikulum 2013 Edisi Revisi Dan Penyusunan Makro Wacana. Jurnal Ilmiah Kanderang Tingang. 10, 2 (Des. 2019), 175-183.

Ormrod, J.E. 2008. Psikologi Pendidikan Membantu Siswa Tumbuh dan Berkembang, Edisi Keenam. Jakarta: Erlangga.

Permendikbud. 2015. Peraturan menteri Pendidikan dan Kebudayaan Republik Indonesia Nomor 11 Tahun 2015 Tentang Penilaian Hasil Belajar Oleh Pendidik dan Satuan Pendidikan Pada Pendidikan Dasar dan Pendidikan Menengah. Jakarta:BSNP.

Rusianti, S., Fatah, A.H. and Mulawi 2019. Analisis Kesesuaian Konsep Ikatan Kimia Pada Buku Kimia Kelas X SMA/MA Terhadap Silabus Kurikulum 2013 Dan Penyusunan Makro Wacana. Jurnal Ilmiah Kanderang Tingang. 10, 2 (Des. 2019), 184-200.

Sari, Nur Komala Eka. 2013. Pengembangan Tes Diagnostik Two-Tier sebagai Instrumen Alternatif untuk Mendeteksi Miskonsepsi Siswa SMA pada Materi Laju Reaksi. Skripsi, tidak diterbitkan. UPI.

Siregar, N. 1994. Studi Penerapan Pedagogi Materi Subyek dalam Penulisan Buku Teks MIPA untuk Mengembangkan Keterampilan Intelektual Mahasiswa IKIP Bandung. Laporan Penelitian, tidak diterbitkan. IKIP.

Sugihartono, Kartika Nur Fathiyah, Farida Harahap, Farida Agus Setiawati, Siti Rohmah Nurhayati. 2006. Psikologi Pendidikan. Yogyakarta: Universitas Negeri 338 Yogyakarta. 
Sukmadinata, N.S., dan Erliana S. 2012. Kurikulum \& Pembelajaran Kompetensi. Bandung: PT Refika aditama.

Suparno, Paul. 2005. Miskonsepsi dan Perubahan Konsep Pendidikan Fisika. Jakarta: PT Grasindo.

Tarigan, H. G. Dan Tarigan, D. 2009. Telaah Buku Teks Bahasa Indonesia. Bandung: Angkasa.

Taluka, Melvie. 2013. Penerapan Model Pembelajaran Berorientasi Perubahan Konseptual Berbantuan Virtual Laboratory untuk Meningkatkan Pemahaman Konsep IPA Mahasiswa Calon Guru SD. Bandung: Universitas Pendidikan Indonesia.

Tasdelen, Ugur dan Koseoglu, Fitnat. 2008. Learner-Friendly Text books: Chemistry Texts Based on a Constructivist View of Learning. Journal Asia Pacific Education Review. Vol. 9, No.2, 136-147.

Vitriani, I.R. 2012. Analisis Wacana Sistem Ekskresi. Bandung: Universitas Pendidikan Indonesia.

Winarni, Sri. 2010. Perlunya Konsep Kimia Secara Benar Pada Buku Ajar Kimia SMA. Jurnal Biologi Edukasi, Fakultas Keguruan Universitas Syiah Kuala vol (1) hlm 42-47.

Wulandari, S.H., Fatah, A.H. and Anggraeni, M.E. 2019. Analisis Materi Ajar Kimia SMA/MA Kelas XII Pada Konsep Sifat Koligatif Larutan. Jurnal Ilmiah Kanderang Tingang. 10, 2 (Des. 2019), 300-320. 